\title{
Assimilation of selenium from phytoplankton by three benthic invertebrates: effect of phytoplankton species
}

\author{
Christian E. Schlekat ${ }^{1, *}$, Byeong-Gweon Lee ${ }^{2}$, Samuel N. Luoma1 \\ ${ }^{1}$ US Geological Survey, Water Resources Division, 345 Middlefield Road, MS 465, Menlo Park, California 94025, USA \\ ${ }^{2}$ Chonnam National University, Department of Oceanography, Kwang Ju, South Korea
}

\begin{abstract}
Phytoplankton are an important source of selenium (Se) for aquatic invertebrates, which accumulate Se primarily through dietary ingestion. The extent to which Se bioavailability varies among different phytoplankton species could help explain different bioaccumulation patterns observed for invertebrates in nature. We measured the efficiency with which 3 benthic invertebrates assimilated ${ }^{75}$ Se from 5 phytoplankton species using standard pulse-chase techniques. The invertebrates included the amphipod Leptocheirus plumulosus and the bivalves Macoma balthica and Potamocorbula amurensis. The phytoplankton species included Cryptomonas sp. (Cryptophyceae), Gymnodinium sanguinem (Dinophyceae), Phaeodactylum tricornutum (Bacillariophyceae), Synechococcus sp. (Cyanophyceae) and Thalassiosira pseudonana (Bacillariophyceae). The range of Se assimilation efficiency (AE) by L. plumulosus (32.1 \pm 1.8 to $69.5 \pm 7.1 \%$ ) was the lowest of the 3 organisms. No relationship was observed between the proportion of Se in algal cell cytoplasm and Se AE by L. plumulosus, which is consistent with findings for assimilation of other trace elements by this organism. Se AE by $M$. balthica (range: $58.0 \pm 3.2$ to $92.3 \pm 6.0 \%$ ) varied according to the proportion of cytoplasmic Se in algal cells $\left(\mathrm{p}<0.0001, \mathrm{r}^{2}=0.868\right)$. P. amurensis assimilated between $78.3 \pm 2.0$ and $88.9 \pm 3.6 \%$ of Se from algal cells, and the relationship between cytoplasmic Se and Se AE was described by the following equation: $\mathrm{Se} \mathrm{AE}=69.2+0.22 \times(\%$ cytoplasmic $\mathrm{Se})\left(\mathrm{p}=0.003, \mathrm{r}^{2}=0.405\right)$. This relationship suggests that $P$. amurensis assimilated non-cytoplasmic Se from phytoplankton, perhaps through utilization of the glandular digestive pathway. Consistently high Se assimilation from algae by $P$. amurensis may contribute to elevated Se concentrations observed for this organism.
\end{abstract}

KEY WORDS: Selenium $\cdot$ Phytoplankton $\cdot$ Bivalves $\cdot$ Amphipods $\cdot$ Bioavailability

\section{INTRODUCTION}

Dietary uptake of particle-associated selenium (Se) can be the dominant pathway for Se bioaccumulation by invertebrates, including bivalves (Luoma et al. 1992) and copepods (Wang \& Fisher 1998). Particleassociated Se can be present in several valence states, including reduced selenide, $\mathrm{Se}(-\mathrm{II})$, elemental $\mathrm{Se}, \mathrm{Se}(0)$ and 2 oxidized forms, Se(IV) and Se(VI) (Cutter 1985,

*Present address: US Borax Inc, 26877 Tourney Road, Valencia, California 91344, USA.

E-mail: chris.schlekat@borax.com
Velinsky \& Cutter 1991, Masscheleyn \& Patrick 1993). Selenide is produced by biological processes, including the uptake and subsequent reduction of selenate and selenite by phytoplankton. This is a potentially important process considering that invertebrates such as the bivalves Macoma balthica and Potamocorbula amurensis assimilated Se associated with algal cells more efficiently than from inorganic particulate forms (Luoma et al. 1992, Schlekat et al. 2000b).

Se bioaccumulation by biota in San Francisco Bay, California, USA, has been an increasing concern. Potamocorbula amurensis is an invasive species in San Francisco Bay, and can reach densities as high as $1.2 \times$ 
$10^{4}$ ind. $\mathrm{m}^{-2}$ (Carlton et al. 1990). As a result of its pervasiveness, $P$. amurensis is frequently eaten by upper trophic level foragers, such as wildfowl and fish. As Se tissue concentrations for $P$. amurensis (10 to $20 \mu \mathrm{g} \mathrm{Se}$ $\mathrm{g}^{-1}$ dry wt [US Geology Survey unpubl. data]) exceed dietary toxicity thresholds reported for wildfowl (Skorupa 1998) and fish (Lemly 1998), the possibility is raised that consumption of $P$. amurensis may lead to negative impacts on upper trophic level wildlife. Identification of specific Se sources for $P$. amurensis is therefore critical to quantify the risk posed to Sesensitive birds and fish.

Bivalves typically assimilate Se from phytoplankton with high efficiencies (Luoma et al. 1992, Wang \& Fisher 1996). For example, Wang \& Fisher (1996) found that Se assimilation by Mytilus edulis from 7 species of phytoplankton was dependent upon the algal species. A diverse phytoplankton community exists in San Francisco Bay, including diatoms, cryptophytes, dinoflagellates, cyanobacteria (Lehman 1996) and other classes of phytoplankton. Data on Se assimilation from phytoplankton taxa representative of a system like San Francisco Bay should be used to assess the potential risk of Se to consumer species that are specific to this ecosystem.

Several studies have demonstrated that assimilation of phytoplankton-associated trace elements (including Se) by herbivorous invertebrates is often directly related to the proportion of trace elements in phytoplankton cell cytoplasm (Reinfelder \& Fisher 1991, Fisher \& Reinfelder 1995, Wang \& Fisher 1996, Lee \& Luoma 1998). Others have shown that the dependence of the assimilation efficiency (AE) on the distribution of metals in the cytosolic fraction of cells is metal- and animal species-dependent. For example, Schlekat et al. (2000a) showed that trace element assimilation by the amphipod Leptocheirus plumulosus was not related to the proportion of metal in algal cytoplasm. This metal- and species-specific response could be partially explained by differences in gut residence time. For example, Lee \& Luoma (1998) showed that assimilation of $\mathrm{Cd}, \mathrm{Cr}$ and $\mathrm{Zn}$ from natural phytoplankton assemblages by Potamocorbula amurensis, with a 1 d gut residence time (Decho \& Luoma 1991), was related to cytoplasmic metal, whereas assimilation by Macoma balthica, with a $3 \mathrm{~d}$ gut residence time, was not. Mechanistic reasons for differences in $\mathrm{AE}$, when they have occurred, are not fully understood.

The objectives of the present study were to: (1) determine if algal species have an effect on the bioavailability of algae-associated Se to 3 benthic invertebrates; and (2) determine if differences in bioavailability are attributable to the proportion of Se in algal cell cytoplasm. We determined the Se AE from 5 algal species, including representatives from the classes Bacillariophyceae, Cyanophyceae, Dinophy- ceae and Cryptophyceae. AEs were measured for the bivalves Potamocorbula amurensis and Macoma balthica, and for the amphipod Leptocheirus plumulosus. $M$. balthica is a facultative suspension/surface depositfeeding bivalve which is widely distributed in North American estuaries and is a resident of San Francisco Bay. L. plumulosus is a facultative suspension/surface deposit-feeding amphipod that is endemic to East Coast estuaries (Holland et al. 1988) that is ecologically and physiologically similar to Corophium sp., which occurs in San Francisco Bay.

\section{MATERIALS AND METHODS}

Experimental invertebrates. Clams were collected from mudflats in San Francisco Bay (Potamocorbula amurensis [shell length 16 to $28 \mathrm{~mm}$ ], Carquinez Strait near Martinez, California, USA; Macoma balthica [shell length 16 to $28 \mathrm{~mm}$ ], Palo Alto, CA) within $1 \mathrm{wk}$ of experiment initiation. Clams were maintained in aerated $12 \%$ seawater at 13 to $15^{\circ} \mathrm{C}$, and received a suspension composed of sediment particles and the diatom Phaeodactylum tricornutum each day. Leptocheirus plumulosus were cultured according to previously described methods (US EPA 1994) in 12\% seawater and adult amphipods ( 0.6 to $0.9 \mathrm{~mm}$ ) were used for experiments.

Phytoplankton radiolabeling. Five phytoplankton species were used in this study. Cryptomonas sp. (Cryptophyceae: LB 2090), Phaeodactylum tricornutum (Bacillariophyceae: 2090), Synechococcus sp. (Cyanophyceae: LB 2624) and Thalassiosira sp. (Bacillariophyceae: LB 2054) were obtained from the UTEX Culture Collection of Algae at The University of Texas, Austin. Gymnodinium sanguinem (Dinophyceae: CCMP 1593) was obtained from the Provasoli-Guillard Phytoplankton Collection Center, West Southbay Harbor, ME. Radiolabeled selenite $\left(\mathrm{Na}_{2}\left[^{75} \mathrm{Se}\right] \mathrm{O}_{3}\right)$ was introduced to log-phase cultures $(500 \mathrm{ml})$ growing in $\mathrm{f} / 2$ media (Guillard \& Ryther 1962) at 15\%. Resulting radioactivity was $960 \mathrm{kBq} \mathrm{l}^{-1}$, and the concentration of radioactive Se was $1.1 \mathrm{nM}$. This concentration is within the range of dissolved Se concentrations that have been measured in San Francisco Bay (Cutter 1989). Following $7 \mathrm{~d}$ of culture in $\mathrm{f} / 2$ media, the radiolabeled algae were harvested on $0.45 \mu \mathrm{m}$ membrane filters (4 algal spp.) or by centrifugation (Cryptomonas) according to methods described by Wang \& Fisher (1996). Then, cells were suspended in $200 \mathrm{ml} 0.2 \mu \mathrm{m}$ filtered seawater. Separate sub-samples $(10 \mathrm{ml})$ of each algal cell suspension were collected on $0.45 \mu \mathrm{m}$ filters to determine the distribution of Se within algal cells (see procedure in 'Selenium distribution in algal cells').

Bioavailability measurements. Bivalves: Bioavailability of algae-associated ${ }^{75} \mathrm{Se}$ to bivalves was mea- 
sured using well-established pulse-chase procedures (Decho \& Luoma 1991, 1994, Lee \& Luoma 1998, Schlekat et al. 2000b). For each treatment, feeding was initiated by placing clams ( $\mathrm{n}=30$ for Potamocorbula. amurensis and 15 or 30 for Macoma balthica) in a 11 beaker containing $800 \mathrm{ml}$ of filtered $(0.45 \mu \mathrm{m})$ seawater ( $T=15^{\circ} \mathrm{C}, \mathrm{S}=12 \%$ ) and $200 \mathrm{ml}$ of algal suspension. $P$. amurensis fed for 30 to $40 \mathrm{~min}$ and $M$. balthica fed for 90 min. After feeding, clams were placed live in scintillation vials ( 2 clams per vial) and the activity of ${ }^{75} \mathrm{Se}$ was determined for $1 \mathrm{~min}$ at 75 to $450 \mathrm{keV}$ using a Wallac gamma counter. This value represented the radioactivity ingested by the bivalves. After gamma counting, each clam/algae combination was split into 2 groups, denoted $T_{0}$ (initial activity) and $T_{\mathrm{F}}$ (final activity). All $P$. amurensis/algae combinations were distributed in this way, but there were only enough $M$. balthica collected to allow for 5 sets of $T_{\mathrm{F}}$ clams (1 set per algal species) and 1 set of $T_{0}$ clams (these were fed Synechococcus sp.). The purpose of the $T_{0}$ clams was to distinguish between activity that was due to ingested cells, as opposed to cells adsorbed onto shells. $T_{0}$ clams were immediately frozen at $-80^{\circ} \mathrm{C}$ and were later dissected. Within 5 min of counting, $T_{F}$ clams were placed as replicates in separate depuration chambers with unlabeled seawater and algae (up to $48 \mathrm{~h}$ for $P$. amurensis and up to $96 \mathrm{~h}$ for $M$. balthica) to allow for defecation of unassimilated material. During depuration, radioactivity in clams and collected feces were monitored periodically. At the end of depuration, clams were frozen at $-80^{\circ} \mathrm{C}$ and were later dissected.

Both $T_{0}$ and $T_{\mathrm{F}}$ clams were dissected within $1 \mathrm{wk}$ of the end of the experiment. Tissues and shells were placed in separate scintillation vials (vials holding tissue were pre-weighed). Subsequent gamma-counting yielded shell:tissue ratios of ${ }^{75} \mathrm{Se}$ activity for $T_{0}$ clams. These shell:tissue ratios were applied to initial ${ }^{75} \mathrm{Se}$ activity for $T_{\mathrm{F}}$ clams to provide an estimate of the total measured ${ }^{75}$ Se activity that was ingested by clams (as opposed to shell-associated activity) for the initial measurement of $T_{\mathrm{F}}$ clams (Lee \& Luoma 1998). For $M$. balthica, shell:tissue ratios for Synechococcus $T_{0}$ clams were used for all algal species. Between 93 and $99 \%$ of the measured radioactivity was associated with clam tissue, regardless of clam species or sampling period. This indicates that a small proportion of cells were sorbed to shells at $T_{0}$, and this sorption should not have an effect on AE calculations.

Amphipods: Modified pulse-chase methods were used for amphipods. Feeding chambers (250 ml glass beakers) were prepared by adding $150 \mathrm{ml}$ seawater $\left(T=20^{\circ} \mathrm{C}\right.$, Salinity $\left.=15 \%\right)$, followed by a thin $(3 \mathrm{~mm})$ layer of a sediment (125 $\mu \mathrm{m}$ sieved) suspension that was added via pipette. Five amphipods were then added to each chamber (4 chambers per treatment). Feeding was initiated by siphoning out $50 \mathrm{ml}$ seawater and replacing with $50 \mathrm{ml}$ radioactive algae. Amphipods fed for $40 \mathrm{~min}$, which is less than the mean gut retention time of 95 min reported for Leptocheirus plumulosus (Schlekat et al. 1999). Feeding was terminated by pouring the contents of feeding chambers over a $0.5 \mathrm{~mm}$ sieve, which retained only amphipods. Amphipods were rinsed thoroughly with clean seawater, placed in scintillation vials and gamma-counted for 2 min. Amphipods were then placed in beakers containing fresh unlabeled seawater, sediment and a suspension of Phaeodactylum. tricornutum. Amphipods were gamma-counted at $t=4$ and $24 \mathrm{~h}$.

Assimilation efficiency. AE was calculated using the following formula:

$$
\mathrm{AE}=\left(\mathrm{A}_{t=\mathrm{F}} / \mathrm{A}_{t=0}\right) \times 100
$$

where $\mathrm{A}_{t=\mathrm{F}}=$ final measured tissue activity and $\mathrm{A}_{t=0}=$ initial ingested activity (Lee \& Luoma 1998). This was used for both clams and amphipods, except that $\mathrm{A}_{t=0}$ for clams was estimated by multiplying initial whole $T_{\mathrm{F}}$ clam activities by shell:tissue ratios that were determined from $T_{0}$ clams.

Selenium distribution in algal cells. To obtain subcellular fractionations, cells collected on $0.45 \mu \mathrm{m}$ membrane filters were subjected to a sequential fractionation procedure based on methods described by

Table 1. Mean selenium assimilation efficiencies (SD in parentheses) from 5 phytoplankton species by the bivalves Macoma balthica and Potamocorbula amurensis, and the amphipod Leptocheirus plumulosus. Algal assimilation efficiencies sharing the same letter for each consumer organism were not significantly different after analysis of variance and Tukey's honestly significant difference test $(\alpha=0.05)$

\begin{tabular}{|c|c|c|c|c|c|}
\hline \multirow[t]{2}{*}{ Consumer organism } & \multicolumn{5}{|c|}{ - Assimilation efficiency (\%) } \\
\hline & Cryptomonas sp. & $\begin{array}{l}\text { Gymnodinium } \\
\text { sanguinem }\end{array}$ & $\begin{array}{l}\text { Phaeodactylum } \\
\text { tricornutum }\end{array}$ & Synechococcus sp. & $\begin{array}{l}\text { Thalassiosira } \\
\text { pseudonana }\end{array}$ \\
\hline M. balthica & $92.3(6.0)^{\mathrm{A}}$ & $58.0(3.2)^{\mathrm{B}}$ & $85.8(4.0)^{\mathrm{A}}$ & $64.9(6.2)^{\mathrm{B}}$ & $90.4(4.0)^{\mathrm{A}}$ \\
\hline P. amurensis & $88.9(3.6)^{\mathrm{A}}$ & $82.6(2.4)^{\mathrm{B}, \mathrm{C}}$ & $80.0(2.9)^{\mathrm{C}}$ & $78.3(2.0)^{\mathrm{C}}$ & $87.3(2.9)^{\mathrm{A}, \mathrm{B}}$ \\
\hline L. plumulosus & $37.6(3.3)^{\mathrm{A}}$ & $\mathrm{nd}^{*}$ & $32.1(1.8)^{\mathrm{A}}$ & $69.5(7.1)^{\mathrm{B}}$ & $40.9(5.4)^{\mathrm{A}}$ \\
\hline
\end{tabular}



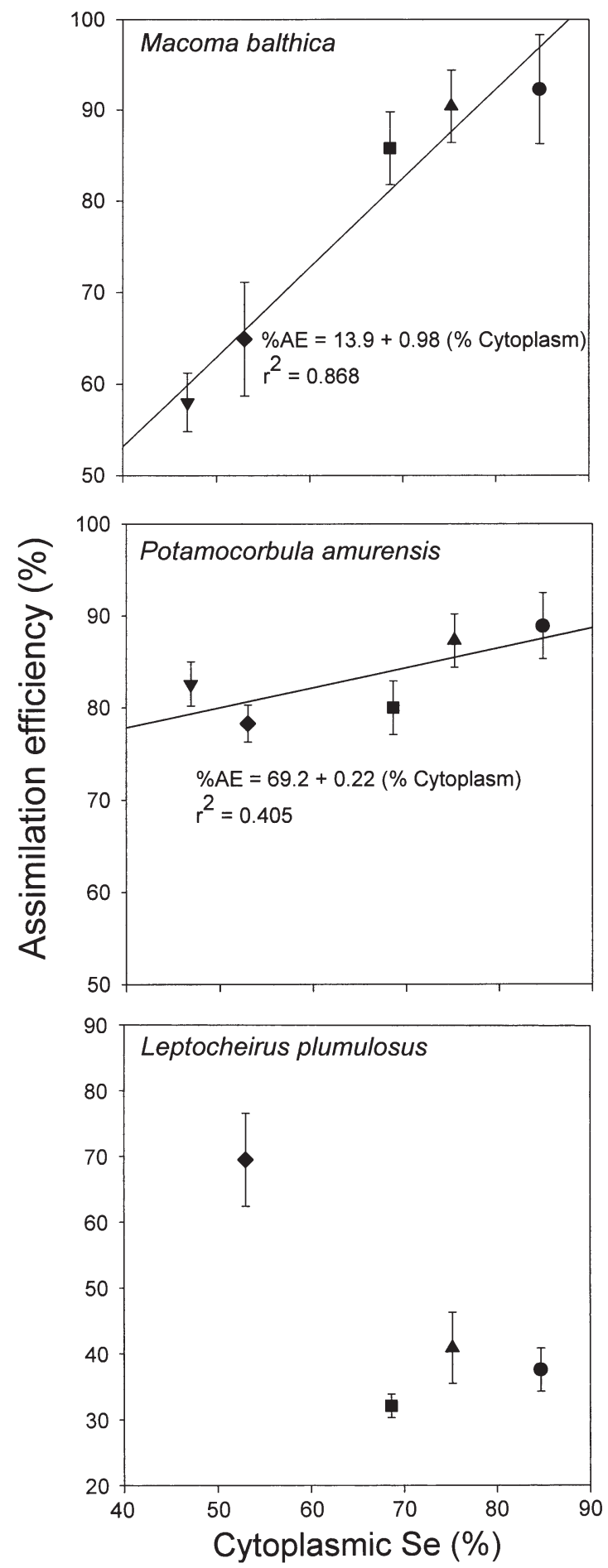

\section{$\boldsymbol{\nabla}$ : Gymnodinium sanguinem $\mathbf{\Delta}$ : Thalassiosira pseudonana \\ - : Synechococcus sp. $\quad$ : Cryptomonas sp. \\ : Phaeodactylum tricornutum}

Fig. 1. Relationship between the distribution of Se within the cell cytoplasm of 5 phytoplankton species and the efficiency with which Se was assimilated by the bivalves Macoma balthica and Potamocorbula amurensis, and the amphipod Leptocheirus plumulosus
Reinfelder \& Fisher (1991). Briefly, cells were lysed by placing filters in Milli Q water and freezing at $-80^{\circ} \mathrm{C}$. Thawed cellular material was then centrifuged at $750 \times g$ for $5 \mathrm{~min}$. This separated cytoplasmic Se (supernatant) from Se associated with cell wall material (pellet). Se AEs from these algae by suspension feeders were compared to the proportion of metal in algal cytoplasm.

\section{RESULTS}

Se AEs by both bivalves varied significantly among the 5 phytoplankton species. AEs by Potamocorbula amurensis was similar among algal species and ranged from $78.3 \pm 2.0 \%$ from Synechococcus sp. to $88.9 \pm$ $3.6 \%$ from Cryptomonas sp. (Table 1). Macoma balthica showed a broader range of AEs, from $58.0 \pm 3.2 \%$ from Gymnodinium sanguinem to $92.3 \pm 6.0 \%$ from Cryptomonas sp. (Table 1). Assimilation by this clam from Cryptomonas sp., Phaeodactylum tricornutum and Thalassiosira pseudonana was significantly more efficient than assimilation from G. sanguinem and Synechococcus sp. (Table 1). Changes in the composition of the phytoplankton community, therefore, could affect Se accumulation by $M$. balthica, but will not affect Se accumulation as much in $P$. amurensis, as long as Se concentrations within different algal cells are the same.

AEs for Leptocheirus plumulosus were generally lower than those of the bivalves. AEs, which ranged from $32.1 \pm 1.8 \%$ from Phaeodactylum tricornutum to $69.5 \pm 7.1 \%$ from Synechococcus sp., were significantly different among 4 algal species $\left(F_{3,12}=48.1, \mathrm{p}<\right.$ 0.0001) (Table 1). Amphipods assimilated Se from Synechococcus sp. more efficiently than from the other 3 species. AE was not measurable from Gymnodinium sanguinem because amphipods did not ingest these species. AE was not measurable from Gymnodinium sanguinguinem cells ( $>100 \mu \mathrm{m}$ in diameter), which is greater than the optimal particle size of $9 \mu \mathrm{m}$ ingested by closely related amphipods (Miller 1984).

The distribution of Se within algal cells differed among the 5 phytoplankton species. Cryptomonas sp. exhibited the highest proportion of Se within cell cytoplasm $(84.7 \%)$ and Gymnodinium sanguinem the lowest $(46.9 \%)$ (Fig. 1). Cytoplasmic Se for Thalassiosira pseudonana was $75.2 \%$, which compares well with the value of $84 \%$ measured by Reinfelder \& Fisher (1991). The same study showed that the majority of non-cytoplasmic Se occurs in the cell walls of algae (Reinfelder \& Fisher 1991).

Trace elements associated with cell wall material are generally thought to be of low bioavailability to herbivorous invertebrates (Reinfelder \& Fisher 1991, Fisher \& Reinfelder 1995). Consistent with this, the efficiency with 
which Macoma balthica assimilated Se from the 5 algal species was strongly related to proportions of cytoplasmic Se ( $p<0.0001, r^{2}=0.868$; Fig. 1$)$, indicating that this bivalve predominately assimilated Se from cell cytoplasm. This is consistent with many past studies in which bivalves have been fed pure algal cultures (Fisher \& Reinfelder 1995, Wang \& Fisher 1996, Reinfelder et al. 1997). In contrast, no relationship between cytoplasmic Se and AE by Leptocheirus plumulosus was observed $\left(\mathrm{p}=0.159, \mathrm{r}^{2}=0.137\right)$. The relationship for Potamocorbula amurensis $\left(\mathrm{p}=0.003, \mathrm{r}^{2}=0.405\right)$ was significant but weak. The $y$-intercept $(0.70)$ indicated that $P$. amurensis can assimilate Se even when cytoplasmic Se is minimal (Fig. 2). AEs from Gymnodinium sanguinem and Synechococcus sp., the algal species showing the lowest proportions of cytoplasmic Se, were not significantly different from AEs from Phaeodactylum tricornutum, which exhibited $>16 \%$ higher cytoplasmic Se (Table 1 ). Thus, at least some non-cytoplasmic fractions of Se are bioavailable to $P$. amurensis. The ability of $P$. amurensis to assimilate non-cytoplasmic Se from phytoplankton may help explain its high Se tissue concentrations in nature (Linville et al. 2002).

\section{DISCUSSION}

Internal feeding mechanisms could play an important role in the differences observed between Se AE and cytoplasmic Se for the different particle feeders used in this study. For example, only a fraction of cells ingested by Leptocheirus plumulosus are ruptured during internal feeding processes (Schlekat et al. 2000b). The limited access to algal cell cytoplasm explained the absence of a relationship between Ag, $\mathrm{Cd}$, and Zn AEs by L. plumulosus and the distributions of these elements within cell cytoplasm of 2 phytoplankton species (Schlekat et al. 2000b). It can also explain the absence of a relationship between cytoplasmic Se and AE for L. plumulosus in the present study, and it probably adds to the variability of Se assimilation by amphipods from phytoplankton. Not only is the distribution of elements within algal cells important for amphipods, but so is the proportion of cells that are ruptured and subject to digestion.

Other digestive processes might be responsible for the differences observed between Macoma balthica and Potamocorbula amurensis. Filter-feeding bivalves utilize dual digestive pathways, in which easily digestible material (e.g. soluble organic material, algal cell cytoplasm) is processed by extracellular enzymes in the intestine, whereas more recalcitrant material (e.g. particulate material, bacterial cells) is phagocytized within the digestive gland. Decho \& Luoma (1991) showed that trace elements that were once thought to be unavailable, e.g. Cr associated with bacterial cell walls, were efficiently assimilated by $P$. amurensis through its glandular pathway. Different utilization of these pathways between $P$. amurensis and $M$. balthica may explain the differences in their Se AEs.

For Potamocorbula amurensis, fecal material egested within $4 \mathrm{~h}$ is the product of intestinal digestion, and glandular feces are produced from 4 to $48 \mathrm{~h}$ post-ingestion (Decho \& Luoma 1991). In Macoma balthica, the cut-off between the dual pathways is about $24 \mathrm{~h}$ (Decho \& Luoma 1991). In the present study, the proportion of radioactivity present in glandular feces from both bivalves

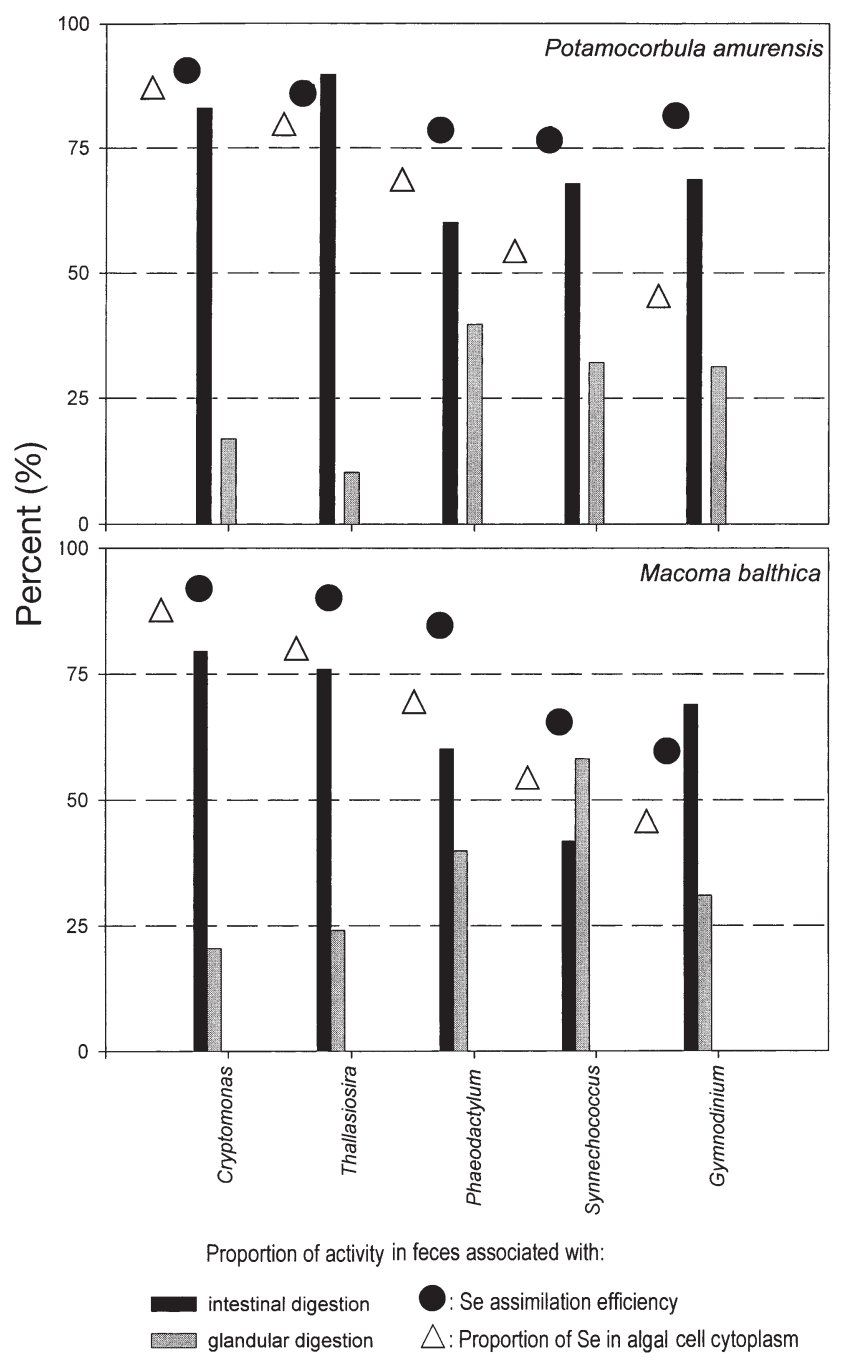

Fig. 2. Proportion of ${ }^{75}$ Se activity in feces of Macoma balthica and Potamocorbula amurensis collected over time as a function of phytoplankton species. Feces were collected at 4 , 24 and $48 \mathrm{~h}$ for $P$. amurensis, and every $24 \mathrm{~h}$ for up to $96 \mathrm{~h}$ for M. balthica. Feces collected within 4 and $24 \mathrm{~h}$ is considered to have been from intestinal digestive processing for $P$. amurensis and $M$. balthica, respectively. Feces collected after these time points are considered to have been processed via glandular processes 
increased as the proportion of cytoplasmic Se within the different algae decreased (Fig. 2). For M. balthica, the increase in activity of glandular feces was accompanied by a corresponding decrease in overall AE (Fig. 2). The difference in $\mathrm{AE}$ among the algal species was thus related to less efficient assimilation from the material that was retained longer than $4 \mathrm{~h}$ in the species with a low proportion of cytoplasmic Se. A decrease in AE from cytosolpoor species was not as dramatic with longer retention in $P$. amurensis compared to $M$. balthica.

Effects of feeding mechanisms on trace element assimilation can be conditional and might be expected to change with different element-particle combinations. For example, Lee \& Luoma (1998a) found that the AEs of $\mathrm{Cd}, \mathrm{Cr}$ and $\mathrm{Zn}$ by Potamocorbula amurensis were related to the proportion of cytoplasmic metal from natural phytoplankton assemblages, whereas Macoma balthica showed no significant relationship. At first, this result appears to be the opposite of the findings of the present study. Lee \& Luoma (1998a) used natural particle suspensions that included both algal cells and nonliving particles. Furthermore, those relationships were based on different trace elements, which exhibited a wide range of AEs, whereas relationships found in the present study were obtained from a single element/ particle combination. The relationship between $\mathrm{AE}$ and cytoplasmic distribution of elements observed by Lee \& Luoma (1998a) could have been influenced by differences in particle selectivity between the 2 bivalves (i.e. selective ingestion of algal cells by $P$. amurensis), as well as differences in the assimilation of elements associated with non-living particles that were ingested. Exposure to trace elements that penetrate algal cell cytoplasm will be greater for those bivalves that selectively ingest algal cells from suspended particles, compared with those that do not exhibit selective feeding. This selectivity may result in different Se accumulation patterns among bivalves, as this element penetrates algal cell cytoplasm and is more efficiently assimilated from algal cells than from inorganic particles (Schlekat et al. 2000b).

Acknowledgements. We thank J. Cloern for helpful experimental design suggestions and A. Stewart for reviewing the manuscript. This work was partly supported by a National Research Council Postdoctoral Research Associateship, funded by the National Research Program of USGS and partly by CALFED Bay Delta Environmental Enhancement Act Contract 1425-98-AA-20-16950.

\section{LITERATURE CITED}

Carlton JT, Thompson JK, Schemel LE, Nichols FH (1990) The remarkable invasion of San Francisco Bay, California, by the Asian clam Potamocorbula amurensis: introduction and dispersal. Mar Ecol Prog Ser 66:81-94
Cutter GA (1985) Determination of selenium speciation in biogenic particles and sediments. Anal Chem 57:2951-2955

Cutter GA (1989) The estuarine behavior of selenium in San Francisco Bay. Estuar Coast Shelf Sci 28:13-34

Decho AW, Luoma SN (1991) Time-courses in the retention of food material in the bivalves Potamocorbula amurensis and Macoma balthica: significance to the absorption of carbon and chromium. Mar Ecol Prog Ser 78:303-314

Decho AW, Luoma SN (1994) Humic and fulvic acids: sink or source in the availability of metals to the marine bivalves Macoma balthica and Potamocorbula amurensis? Mar Ecol Prog Ser 108:133-145

Decho AW, Luoma SN (1996) Flexible digestion strategies and trace metal assimilation in marine bivalves. Limnol Oceanogr 41(3):568-572

Fisher NS, Reinfelder JR (1995) The trophic transfer of metals in marine systems. In: Tessier A, Turner DR (eds) Metal speciation and bioavailability in aquatic systems. WileyLiss, New York, p 363-406

Guillard RRL, Ryther JH (1962) Studies of marine phytoplanktonic diatoms. 1. Cyclotella nana Hustedt and Detonula confervacea (Cleve) Gran. Can J Microbiol 8:229-239

Holland AF, Shaughnessy AT, Scott LC, Dickens VA, Ranasinghe JA, Summers JK (1988) Progress report: long term benthic monitoring and assessment program for the Maryland portion of the Chesapeake Bay (July 1986-October 1987). PPRB-LTB/EST-88-1. VERSAR, Columbia, MD

Lee BG, Luoma SN (1998) Influence of microalgal biomass on absorption efficiency of $\mathrm{Cd}, \mathrm{Cr}$, and $\mathrm{Zn}$ by two bivalves from San Francisco Bay. Limnol Oceanogr 43(7):1455-1466

Lehman PW (1996) Changes in chlorophyll a concentration and phytoplankton community composition with wateryear type in the upper San Francisco Bay estuary. In: Hollibaugh JT (ed) San Francisco Bay: the ecosystem. Pacific Division, American Association for the Advancement of Science, San Francisco, p 351-374

Lemly AD (1998) Pathology of selenium poisoning in fish. In: Frankenberger J, William T, Engberg RA (eds) Environmental chemistry of selenium. Marcel Dekker, New York, p 281-298

Linville RG, Luoma SN, Cutter L, Cutter GA (2002) Increased selenium threat as a result of invasion of the exotic bivalve Potamocorbula amurensis into San Francisco Bay-Delta. Aquat Toxicol 57:51-64

Luoma SN, Johns C, Fisher NS, Steinberg NA, Oremland RS, Reinfelder JR (1992) Determination of selenium bioavailability to a benthic bivalve from particulate and solute pathways. Environ Sci Technol 26(3):485-491

Masschelyn PH, Patrick WH Jr (1993) Biogeochemical processes affecting selenium cycling in wetlands. Environ Toxicol Chem 12:2235-2243

Miller D (1984) Mechanical post-capture particle selection by suspension- and deposit-feeding Corophium. J Exp Mar Biol Ecol 82:59-76

Reinfelder JR, Fisher NS (1991) The assimilation of elements ingested by marine copepods. Science 251:794-796

Reinfelder JR, Wang WX, Luoma SN, Fisher NS (1997) Assimilation efficiencies and turnover rates of trace elements in marine bivalves - a comparison of oysters, clams and mussels. Mar Biol 129(3):443-452

Schlekat CE, Decho AW, Chandler GT (1999) Dietary assimilation of cadmium associated with bacterial exopolymer sediment coatings by the estuarine amphipod Leptocheirus plumulosus: Effects of Cd concentration and salinity. Mar Ecol Prog Ser 183:205-216

Schlekat CE, Decho AW, Chandler GT (2000a) Bioavailability of particle-associated silver, cadmium, and zinc to the 
estuarine amphipod Leptocheirus plumulosus through dietary ingestion. Limnol Oceanogr 45(1):11-21

Schlekat CE, Dowdle PR, Lee BG, Luoma SN, Oremland RS (2000b) Bioavailability of particle-associated Se to the bivalve Potamocorbula amurensis. Environ Sci Technol 34(21):4504-4510

Skorupa J (1998) Selenium poisoning of fish and wildlife in nature: lessons from twelve real-world examples. In: Frankenberger J, William T, Engberg RA (eds) Environmental chemistry of selenium. Marcel Dekker, New York, p 315-352

US EPA (US Environmental Protection Agency) (1994) Meth-

Editorial responsibility: Otto Kinne (Editor),

Oldendorf/Luhe, Germany ods for assessing the toxicity of sediment-associated contaminants with estuarine and marine amphipods. EPA 600/R-94/025. June 1994 US EPA, Office of Research and Development, Narragansett, RI

Velinsky DJ, Cutter GA (1991) Geochemistry of selenium in a coastal salt marsh. Geochim Cosmochim Acta 55: 179-191

Wang WX, Fisher NS (1996) Assimilation of trace elements and carbon by the mussel Mytilus edulis: effects of food composition. Limnol Oceanogr 41(2):197-207

Wang WX, Fisher NS (1998) Accumulation of trace elements in a marine copepod. Limnol Oceanogr 43(2):273-283

Submitted: September 20, 2000; Accepted: March 12, 2002 Proofs received from author(s): June 17, 2002 